\title{
Antioxidative system response of pedunculate oak (Quercus robur L.) seedlings to $\mathrm{Cd}$ exposure
}

\author{
Magdalena Sozoniuk ${ }^{1} \cdot$ Michał Nowak $^{1} \cdot$ Karolina Dudziak $^{1,3} \cdot$ Piotr Bulak $^{2}$ • \\ Justyna Leśniowska-Nowak ${ }^{1}$ (D) Krzysztof Kowalczyk $^{1}$
}

Received: 17 April 2019/Revised: 18 August 2019/Accepted: 29 August 2019/Published online: 4 October 2019

(C) The Author(s) 2019

\begin{abstract}
The use of pedunculate oak (Quercus robur L.), along with other tree species, for the afforestation of heavy metal contaminated lands is an attractive prospect. Little, however, is known of $Q$. robur tolerance and its antioxidative system response to heavy metal exposure. The main objective of the study was to determine the cadmium-induced changes in antioxidative system of pedunculate oak in an attempt to identify molecular mechanisms underlying Cd tolerance. This may be of great importance in respect of using $Q$. robur for phytoremediation purposes. As the response of the antioxidative system to heavy metal contamination can vary within species, the research was conducted on oak seedlings from two different regions of origin. Differences in antioxidative system response of seedlings derived from tested regions of origin were noticed both at the transcript and enzyme activity levels. The obtained results indicate that ascorbate peroxidase (APX; EC 1.11.1.11) and superoxide dismutase (SOD; EC 1.15.1.1) play a first barrier role in oak seedlings response to the oxidative stress caused by $\mathrm{Cd}$ exposure. Catalase (CAT; EC 1.11.1.6) is involved in reducing the negative effects of prolonged Cd treatment.
\end{abstract}

Justyna Leśniowska-Nowak

justyna.lesniowska@up.lublin.pl

1 Institute of Plant Genetics, Breeding and Biotechnology, University of Life Sciences in Lublin, Akademicka 15 St., 20-950 Lublin, Poland

2 Institute of Agrophysics, Polish Academy of Sciences, Doswiadczalna 4 St., 20-290 Lublin, Poland

3 Chair and Department of Biochemistry and Molecular Biology, Medical University of Lublin, Chodźki 1 St., 20-093, Lublin, Poland
Keywords Pedunculate oak - Antioxidative enzymes activity $\cdot$ Gene expression $\cdot \mathrm{Cd}$

\section{Introduction}

Heavy metal contamination of soils is a serious problem of the modern world (Mihucz et al. 2012). Cadmium is recognized as one of the most toxic pollutant due to its high mobility and low amount needed to cause the toxicity symptoms. $\mathrm{Cd}$ accumulation in plants affects many cellular and physiological processes such as nitrogen metabolism or mineral uptake (Benavides et al. 2005; DalCorso et al. 2008; Wu et al. 2015). Cd was shown to induce ultrastructural damage to chloroplasts, which subsequently affects photosynthesis and causes decline in biomass production. Moreover, decrease in Rubisco protein content was reported in $\mathrm{Cd}$ affected plants (Arena et al. 2017; Figlioli et al. 2019). However, plants showing high Cd tolerance revealed increased Rubisco level, thus mitigating $\mathrm{Cd}$ effect on biomass production. Other mechanisms allowing species to endure $\mathrm{Cd}$ pollution include metal complexation by chelating agents or its compartmentalization (Sorrentino et al. 2018). As cadmium causes oxidative stress (Mihucz et al. 2012), an adequate antioxidative system reaction is also a fundamental cell defense mechanism. The activation of antioxidative enzymes helps to protect plant against oxidative injury evoked by heavy metals (DalCorso et al. 2008). Among others, major antioxidative enzymes are superoxide dismutase (SOD; EC 1.15.1.1), catalase (CAT; EC 1.11.1.6) and ascorbate peroxidase (APX; EC 1.11.1.11) (Mittler 2002). SOD catalyzes the dismutation of $\mathrm{O}_{2}^{--}$to $\mathrm{H}_{2} \mathrm{O}_{2}$, which is subsequently detoxified by CAT and APX (Sharma and Dietz 2009). 
There are numerous studies reporting heavy metal-induced changes in antioxidative system of crop plants (Ekmekçi et al. 2008; El-Beltagi et al. 2010; Khan et al. 2007; Malecka et al. 2014; Rodriguez-Serrano et al. 2009). The studies conducted on forest trees response to heavy metal stress focus mainly on various Populus and Salix species, mostly due to their industrial importance and fast growth rate (Gaudet et al. 2011; Ge et al. 2012; He et al. 2013; Landberg and Greger 2002; Nikolić et al. 2008). Little, however, is known about other tree species response to heavy metal stress (Schützendübel et al. 2001). Some of defense mechanisms against $\mathrm{Pb}$ and $\mathrm{Cd}$ induced stress have been investigated in Quercus ilex (Arena et al. 2017).

Studies performed on Quercus pubescens and Quercus suber suggest their possible use in phytoremediation practices (Paoletti and Günthardt-Goerg 2006; Gogorcena et al. 2011). Thus, the understanding of molecular mechanisms underlying heavy metal tolerance in Quercus species could be vital for selection and breeding of trees suitable for the phytoremediation. Efficient detoxification strategies, such as prompt activation of antioxidative enzymes, may alleviate negative effects of $\mathrm{Cd}$ on trees growth and development. This may be of great importance in context of utilizing Quercus robur for the afforestation of heavy metal contaminated lands. The main objective of present research was to determine the antioxidative system response of pedunculate oak to the $\mathrm{Cd}$ treatment in an attempt to identify molecular mechanisms underlying $\mathrm{Cd}$ tolerance. As the response of the antioxidative system to heavy metal contamination can vary within species (Anjum et al. 2008; Gonnelli et al. 2001; Landberg and Greger 2002; Wu et al. 2003), the research was conducted on oak seedlings from two different regions of origin. To our best knowledge, this is the first study that aimed to assess changes induced by $\mathrm{Cd}$ in $Q$. robur leaves both at transcript and enzyme activity levels.

\section{Materials and methods}

\section{Plant material and growth conditions}

One-year old pedunculate oak (Quercus robur L.) seedlings were obtained from two different regions of originNo. 659 (Swidnik Forest District, Poland) and No. 455 (Lubartow Forest District, Poland). Plants were grown hydroponically in the modified Hoagland solution which contained $(\mathrm{mM}) 1.25 \mathrm{Ca}\left(\mathrm{NO}_{3}\right)_{2} \cdot 4 \mathrm{H}_{2} \mathrm{O}, 1.25 \mathrm{KNO}_{3}, 0.25$ $\mathrm{NH}_{4} \mathrm{H}_{2} \mathrm{PO}_{4}, 0.5 \mathrm{MgSO}_{4}$ and $(\mu \mathrm{M}) 22.5 \mathrm{FeSO}_{4} \cdot 7 \mathrm{H}_{2} \mathrm{O}, 11.6$ $\mathrm{H}_{3} \mathrm{BO}_{3}, \quad 0.19 \quad \mathrm{ZnSO}_{4} \cdot 7 \mathrm{H}_{2} \mathrm{O}, \quad 0.08 \quad \mathrm{CuSO}_{4} \cdot 5 \mathrm{H}_{2} \mathrm{O}, \quad 2.29$ $\mathrm{MnSO}_{4} \cdot 4 \mathrm{H}_{2} \mathrm{O}, 0.03 \mathrm{Na}_{2} \mathrm{MoO}_{4} \cdot 2 \mathrm{H}_{2} \mathrm{O}$. Plants were kept in PP tubs (30 seedlings per tub, each tub containing 301 of nutrient solution). The nutrient solution was constantly aerated and changed every 4 days. The $\mathrm{pH}$ of nutrient solution was adjusted to 5.8 every 2 days. Plants were grown in $14 \mathrm{~h}$ day $\left(120 \mu \mathrm{mol} \mathrm{m} \mathrm{m}^{-2} \mathrm{~s}^{-1}\right) / 10 \mathrm{~h}$ night photoperiod at $25 \pm 3{ }^{\circ} \mathrm{C}$. After 21 days of acclimatization, the nutrient solution was supplemented with $\mathrm{CdCl}_{2}$ (10 or $50 \mu \mathrm{M})$ or remained unsupplemented (control plants). The leaf samples for transcriptomic and biochemical analyses were cut from fully expanded leaves [10th stage of leaf development according to Spieß et al. (2012)] after $1 \mathrm{~h}$, 3 h, 24 h, 3 days and 7 days of Cd stress.

\section{Gene expression analysis}

Total RNA was extracted from leaves according to the method of Le Provost et al. (2007) based on CTAB extraction and $\mathrm{LiCl}$ precipitation. The concentration and purity of RNA was assessed with NanoDrop 2000 spectrophotometer (Thermo Scientific). The integrity of RNA samples was analysed by means of electrophoresis in $2 \%$ agarose gel stained with ethidium bromide. Genomic DNA was removed by DNase I (Ambion) treatment. The reaction of reverse transcription was performed on $1 \mu \mathrm{g}$ RNA with SuperScript VILO cDNA Synthesis Kit (Life Technologies) according to the supplier's recommendations. Obtained cDNA was used as template in the qPCR analysis.

The transcript levels of $\mathrm{Cu} / \mathrm{Zn}$-SOD (GenBank Accession No. FN719644), CAT (GenBank Accession No. FN999264) and APX (GenBank Accession No. FP062995) were determined by real-time PCR analysis. Reference gene selection was performed. The GAPDH gene was used as an internal control to normalize the data. The sequence of GAPDH (ID6744996) was obtained from the Fagaceae database, Fagaceae Genome Web (http://www.fagaceae. org/). Primers and TaqMan probes used in experiment (Table 1) were designed with AlleleID ${ }^{\circledR}$ (Premier Biosoft) and Primer3Plus. Primers for GAPDH were taken from Marum et al. (2012). Probes were labelled with FAM/ BHQ1. Real time-PCR was carried out according to the following cycling program: $2 \mathrm{~min}$ at $50{ }^{\circ} \mathrm{C}, 10 \mathrm{~min}$ at $95{ }^{\circ} \mathrm{C}, 40$ cycles of $15 \mathrm{~s}$ at $95{ }^{\circ} \mathrm{C}$ and $1 \mathrm{~min}$ at $60{ }^{\circ} \mathrm{C}$ in a total reaction volume of $20 \mu \mathrm{l}$ containing $1 \times$ TaqMan Gene Expressiom Master Mix (Applied Biosystems), $400 \mathrm{nM}$ of each primer, $250 \mathrm{nM}$ of probe and $100 \mathrm{ng}$ cDNA. Transcriptomic analyses were conducted in three biological replicates (each pooled from ten plants) with three technical replicates for each sample. No-template controls were included in analyses. The amplification was carried out on Mx3005P apparatus with MxPro software (Stratagene). The relative quantification of transcript levels was performed according to Livak and Schmittgen (2001). 
Table 1 Sequences of primers and probes used for real-time PCR

\begin{tabular}{lll}
\hline Gene & Oligo name & Sequence $\left(5^{\prime} \rightarrow 3^{\prime}\right)$ \\
\hline Cu/Zn-SOD & SOD-F & CACTGGTACAGTCAAACC \\
& SOD-R & GTGGACATGAACTAAGTCTG \\
& SOD-probe & CCACAAGCCAATCTTCCACCT \\
CAT & CAT-F & GTGTGAAGACTTTCTGGA \\
& CAT-R & GTCCGTGATGGTATGAAA \\
& CAT-probe & AGTCTACAATCCTCCAATTCTCCTGA \\
APX & APX-F & CTAGACACCAGACAGCAGCC \\
& APX-R & AGGATGCCTTCTTTGCCGAT \\
& APX-probe & CGGCAAATCCAAGTTCTGAGAGC \\
GAPDH & GAPDH-F & ACCGACTTCATTGGTGACAG \\
& GAPDH-R & AGATGCGATGTGGACAATCA \\
& GAPDH-probe & TACAGTTCCCGTGTGGTTGA \\
\hline
\end{tabular}

\section{Crude homogenate and enzyme extract preparation}

The $200 \mathrm{mg}$ of leaves tissue was ground to a fine powder in liquid nitrogen and homogenized in $4.5 \mathrm{ml}$ of pre-cooled $50 \mathrm{mM}$ phosphate buffer ( $\mathrm{pH} 7.5$ ) containing $0.1 \mathrm{mM}$ EDTA and 2\% PVP. The homogenate was filtered through a nylon cloth. A part of the filtrate, defined as crude homogenate, was used to assess the level of lipid peroxidation (LPO). The second part of filtrate was centrifuged at $11,000 \mathrm{rpm}$ for $20 \mathrm{~min}$ at $4{ }^{\circ} \mathrm{C}$ (Balakhnina et al. 2015). The supernatant was used to determine the protein content and enzymes activities. Data shown are mean \pm SD of six biological samples, each taken pooling material from five plants.

\section{Lipid peroxidation (LPO) analysis}

The level of lipid peroxidation, in terms of thiobarbituric acid reactive substances (TBARS), was estimated according to the method developed by Uchiyama and Mihara (1978), using the extinction coefficient of $156 \mathrm{mM}^{-1}$ $1 \mathrm{~cm}^{-1}$. The TBARS concentration was expressed as nmol TBARS $\mathrm{g}^{-1}$ fresh weight (FW). Lipid peroxidation was determined using Hach Lange DR 2800 spectrophotometer.

\section{Determination of antioxidative enzymes}

The activity of SOD (EC 1.15.1.1) was determined according to the method of Giannopolitis and Ries (1977). One unit (1 U) of SOD activity was defined as the amount of enzyme required to cause a $50 \%$ inhibition in the rate of NBT reduction. The activity of APX (EC 1.11.1.11) was determined according to Nakano and Asada (1981) and expressed as $\mu \mathrm{mol}$ of substrate (ascorbate) $\mathrm{min}^{-1} \mathrm{mg}^{-1}$ protein. The activity of CAT (EC 1.11.1.6) was estimated following the method of Aebi (1984), using the extinction coefficient of $39.4 \mathrm{mM}^{-1} 1 \mathrm{~cm}^{-1}$. The CAT activity was expressed as $\mu \mathrm{mol}$ of substrate $\left(\mathrm{H}_{2} \mathrm{O}_{2}\right) \mathrm{min}^{-1} \mathrm{mg}^{-1}$ protein. Total soluble protein content was determined according to the method of Bradford (1976) using the bovine serum albumin (BSA) as a calibration standard. Protein content and SOD activity were measured using Hach Lange DR 2800 spectrophotometer, while CAT and APX activities were assessed using Shimadzu UV-Vis 160A spectrophotometer.

\section{Statistical analysis}

To detect significant differences in the expression levels of $C u / Z n-S O D, C A T$ and $A P X$ between Cd-treated and control plants, the nonparametric Wilcoxon signed-rank test was used. For TBARS content, SOD, APX and CAT activities, two-way ANOVAs with repeated measures were applied (Cd concentration and region of origin as two factors) followed by post hoc Bonferroni corrections. When the condition of sphericity has not been met (Mauchly's test), Greenhouse-Geisser correction was applied. All statistical tests were performed with SPSS 22.0 software.

\section{Results}

\section{Analysis of gene expression}

The Cd treatment resulted in a sustained decrease in the $\mathrm{Cu} / \mathrm{Zn}$-SOD expression compared with the control (Fig. 1a, b), except for an increase $(p \leq 0.01)$ found at $3 \mathrm{~h}$ after the application of $10 \mu \mathrm{M} \mathrm{Cd}$ in No. 659 seedlings. The expression of $A P X$ was upregulated in first hours of stress and then decreased, as compared to respective controls (Fig. 1c, d). The seedlings from tested regions of origin differed in their reaction time. In low dose treated plants, $A P X$ was downregulated after 3 days $(p \leq 0.01)$ or 7 days $(p \leq 0.01)$ of exposure for No. 455 and No. 659 regions of 
Fig. 1 Gene expression in leaves of Nos. 659 and 455 seedlings exposed to $10 \mu \mathrm{M}$ $\mathrm{CdCl}_{2}$ or $50 \mu \mathrm{M} \mathrm{CdCl}_{2}$. Changes in transcript levels were presented as a fold change in comparison to their respective controls. Data are the means of three replicates $( \pm \mathrm{SD})$. Asterisks indicate significant differences between $\mathrm{Cd}$ treated and control plants in the same exposure time (Wilcoxon signed-rank test, ${ }^{*} p \leq 0.05 ; * * p \leq 0.01$; $* * * p \leq 0.001)$
A No. 659

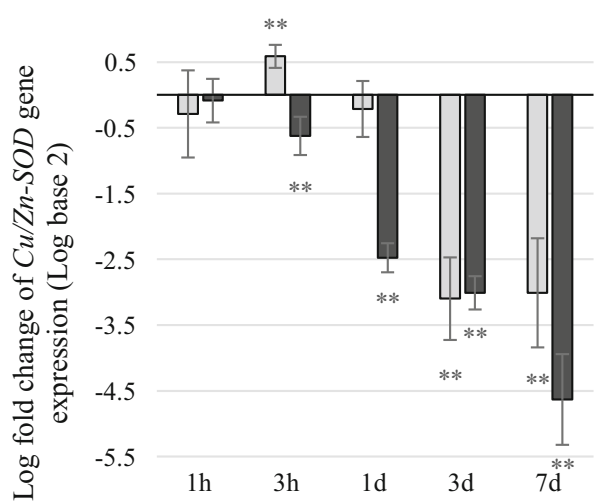

C

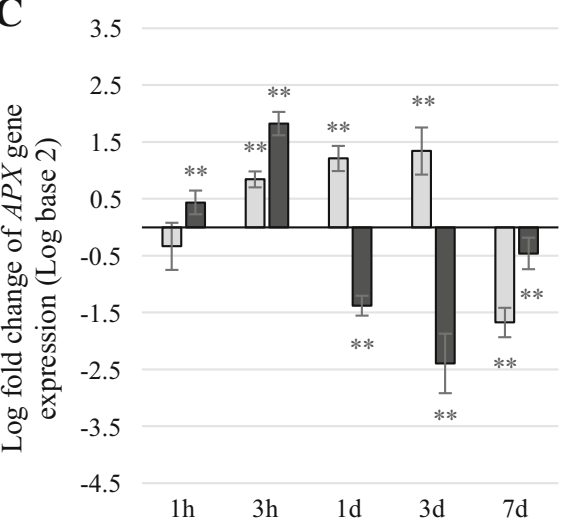

$\mathbf{E}$

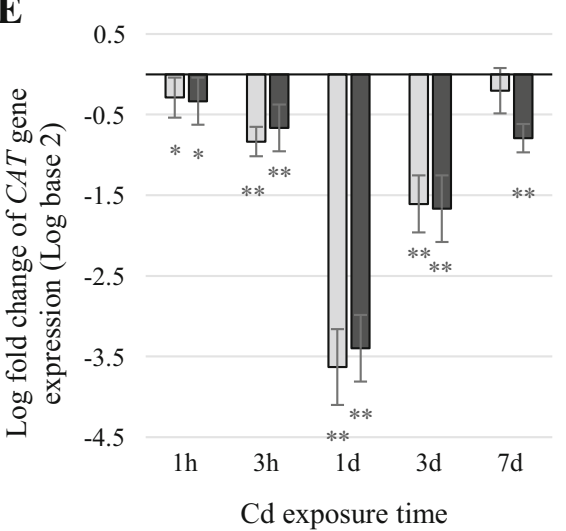

B

No. 455

$\square 10 \mu \mathrm{M}$

$\square 50 \mu \mathrm{M}$

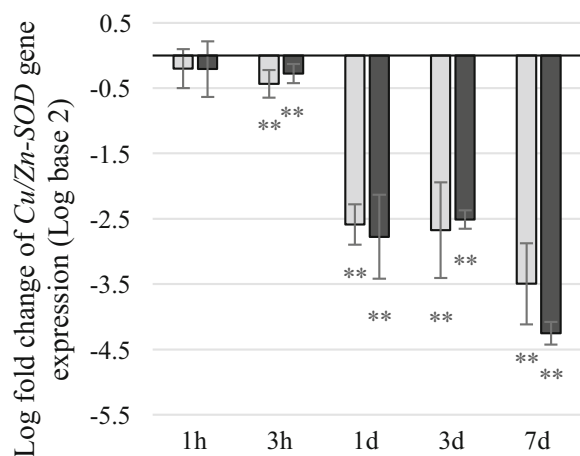

D

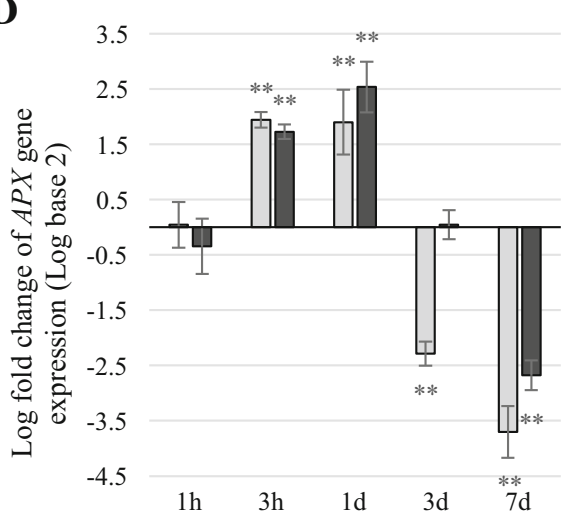

F

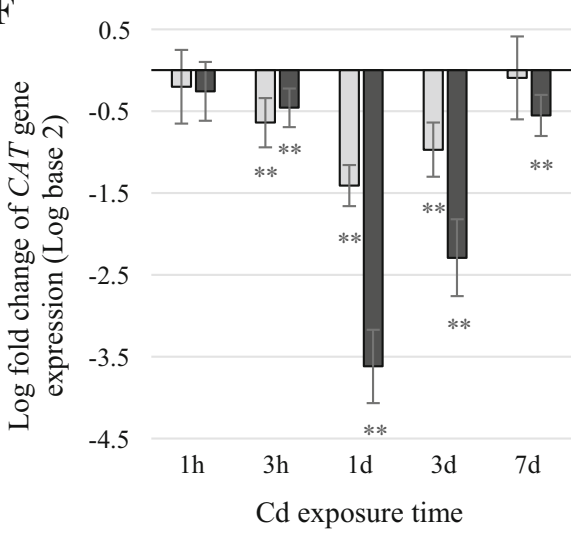

origin, respectively. No. 659 plants showed a decrease $(p \leq 0.01)$ in the $A P X$ expression level 1 day after the application of $50 \mu \mathrm{M} \mathrm{Cd}$ while in No. 455 plants, a decrease $(p \leq 0.01)$ was found after 7 days of treatment. The transcript level of $C A T$ was downregulated by $\mathrm{Cd}$ treatment with great decrease $(p \leq 0.01)$ found after 1 day of exposure, compared to respective controls. Both $\mathrm{Cd}$ doses caused similar changes in CAT expression in No. 659 plants (Fig. 1e) while No. 455 plants were more affected by higher $\mathrm{Cd}$ dose (Fig. 1f).

\section{Analysis of lipid peroxidation (LPO)}

High Cd dose caused increase $(p \leq 0.05)$ in TBARS content in the leaves of No. 659 plants after 1 day, 3 days and 7 days of exposure, while in No. 455 plants, after 1 day and 7 days $(p \leq 0.05)$ of exposure, compared to their 
respective controls (Fig. 2a, b). The maximal content of TBARS was observed at the end of treatment and averaged $180.7 \pm 19.4 \mathrm{nmol}$ TBARS $\mathrm{g}^{-1} \mathrm{FW}$ for No. 659 and $139.9 \pm 14.6 \mathrm{nmol}$ TBARS $\mathrm{g}^{-1} \mathrm{FW}$ for No. 455 . There was no difference $(p>0.05)$ in TBARS concentration between the control and the low dose plants. Interestingly, differences in LPO between plants of different region of origin treated with $50 \mu \mathrm{M} \mathrm{Cd}$ were revealed. After 3 days and 7 days of exposure, the TBARS content in No. 659 was $18 \%(p \leq 0.05)$ and $29 \%(p \leq 0.001)$ higher than in No. 455 , respectively.

\section{Analysis of antioxidative enzyme activity}

SOD activity was initially stimulated by $\mathrm{Cd}$ exposure in plantlets from both regions of origin (Fig. 3a, b). However, after 7 days of Cd treatment, SOD activity in No. 455 leaves declined to the level observed in control $(10 \mu \mathrm{M} \mathrm{Cd})$ or decreased by $16 \%$ as compared to control $(p \leq 0.01$; $50 \mu \mathrm{M} \mathrm{Cd}$ ). In contrast, No. 659 leaves in 7 days of experiment showed increase in SOD activity by $40 \%$ ( $p$ $\leq 0.001 ; 10 \mu \mathrm{M} \mathrm{Cd})$ or $19 \%(p \leq 0.01 ; 50 \mu \mathrm{M} \mathrm{Cd})$ as compared to their respective controls.

As shown in Fig. 3c, d, APX activity in plants treated with $\mathrm{Cd}$ was generally increased. However, No. 659 seedlings responded differently to tested $\mathrm{Cd}$ doses. In low dose treated plants, no changes $(p>0.05)$ in APX activity were observed until 7 days of exposure (increase by $23 \%$ relative to control; $p \leq 0.05$ ). High $\mathrm{Cd}$ dose caused increase in APX activity already after $3 \mathrm{~h}$ of treatment (by
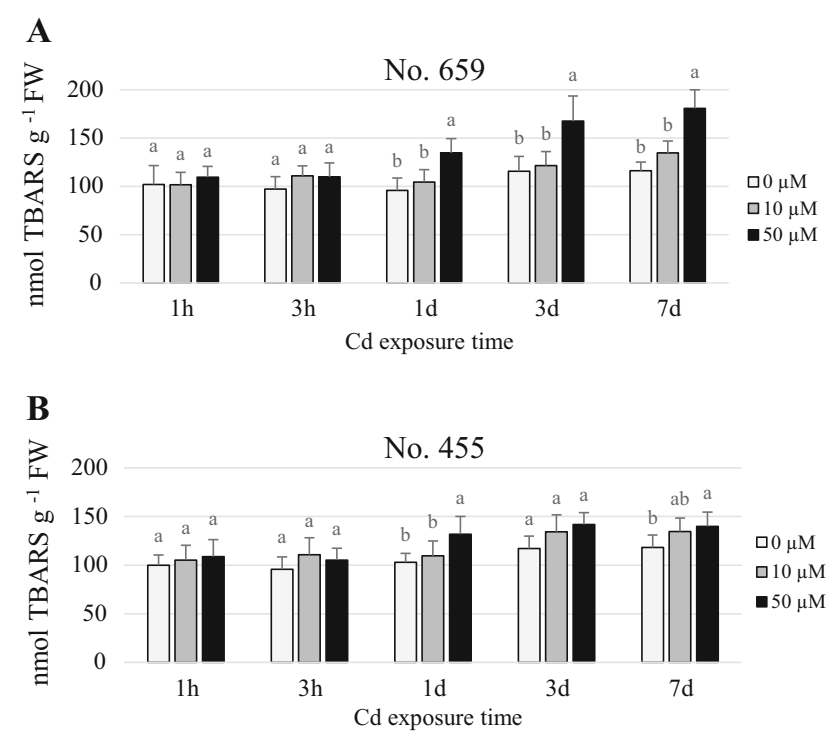

Fig. 2 TBARS content in leaves of $Q$. robur seedlings from No. 659 (a) and No. 455 (b) regions of origin, exposed to $0 \mu \mathrm{M}, 10 \mu \mathrm{M}$ or $50 \mu \mathrm{M}$ Cd. Data are the means of six replicates $( \pm \mathrm{SD})$. Different letters on the bars indicate significant difference between treatments within the same exposure time (Bonferroni test, $p \leq 0.05$ )
$37 \% ; p \leq 0.05$ ). Plants from No. 455 region of origin reacted similarly to both $\mathrm{Cd}$ concentrations, showing constant stimulation of APX activity from $3 \mathrm{~h}$ of treatment to the end of experiment.

In contrast to APX, CAT activity in No. 659 plants decreased by $32 \%$ after $3 \mathrm{~h}$ in $50 \mu \mathrm{M}$ Cd treated plants $(p \leq 0.05)$ or by $37 \%$ after 1 day in $10 \mu \mathrm{M} \mathrm{Cd}$ treated plants $(p \leq 0.01)$ as compared to their respective controls. It remained declined till the end of experiment (Fig. 3e). CAT activity in No. 455 seedlings was initially stimulated (by $29 \%$ after $3 \mathrm{~h}$ of $10 \mu \mathrm{M}$ Cd treatment; $p \leq 0.05$ or by $25 \%$ after 1 day of $50 \mu \mathrm{M}$ treatment; $p \leq 0.05$ ), then declined by $23 \%(p \leq 0.01)$ or by $48 \%(p \leq 0.001)$ after 3 days of 10 or $50 \mu \mathrm{M}$ Cd treatment, respectively. Subsequently, an increase of CAT activity was observed, reaching control level $(p>0.05)$ in low dose plants or surpassing control level by $26 \%(p \leq 0.01)$ in high dose plants (Fig. 3f).

It is notable that in most cases significant differences $(p \leq 0.01)$ in enzyme activities were observed between the two regions of origin under the same $\mathrm{Cd}$ treatments (data not shown). Enzyme activities were generally higher in No. 455 plants than No. 659 plants, both in control conditions and upon $\mathrm{Cd}$ treatment. Only CAT activities in control plants did not differ $(p>0.05)$ between both regions of origin.

\section{Discussion}

Cd accumulation in plants induces oxidative stress (DalCorso et al. 2008). Oxidative damage caused by ROS (reactive oxygen species) may be expressed as the level of lipid peroxidation (Landberg and Greger 2002). In present study, LPO increase was observed in $50 \mu \mathrm{M}$ Cd treated plants already after 1 day of exposure, whereas $10 \mu \mathrm{M} \mathrm{Cd}$ treatment caused no changes in LPO level throughout the whole experiment. The LPO level was dose- and timedependent which is in accordance with the results obtained by Martínez Domínguez et al. (2010) and Mishra et al. (2006).

Cd can stimulate or inhibit the activity of major antioxidative enzymes, such as SOD, CAT and APX (Wójcik et al. 2006). Present study showed that Cd exposure increased SOD and APX activity in pedunculate oak leaves, while CAT displayed differential trend of response. The stimulation of SOD observed already in $3 \mathrm{~h}$ of treatment (Fig. 3a, b) suggests that this enzyme is a component of early phase response mechanism to $\mathrm{Cd}$ exposure in pedunculate oak leaves. As SOD is a source of $\mathrm{H}_{2} \mathrm{O}_{2}$ in cells (Apel and Hirt 2004; Rubio et al. 2004), its stimulation inevitably leads to an increase in cellular $\mathrm{H}_{2} \mathrm{O}_{2}$ concentration. $\mathrm{H}_{2} \mathrm{O}_{2}$ at low concentration acts as signal 
Fig. 3 Change of antioxidative enzyme activity in leaves of Nos. 659 and 455 seedlings exposed to $10 \mu \mathrm{M} \mathrm{CdCl}_{2}$ or $50 \mu \mathrm{M} \mathrm{CdCl}_{2}$. Enzyme activities were expressed relative to the activity in control plants ( $=0 \%$, dashed line). Data are the means of six replicates $( \pm \mathrm{SD})$. Asterisks indicate significant differences between Cd treated and control plants in the same exposure time (Bonferroni test, $* p \leq 0.05$; $* * p \leq 0.01 ; * * * p \leq 0.001)$
A

No. 659

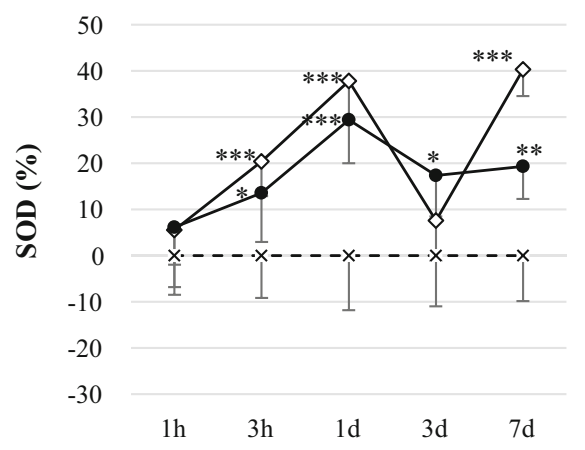

C

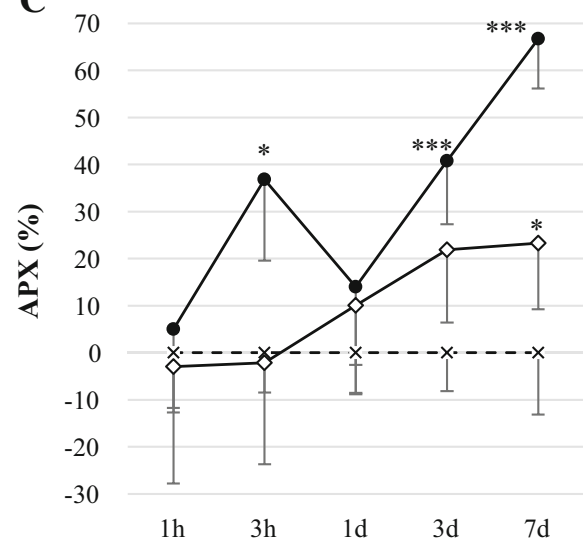

$\mathbf{E}$

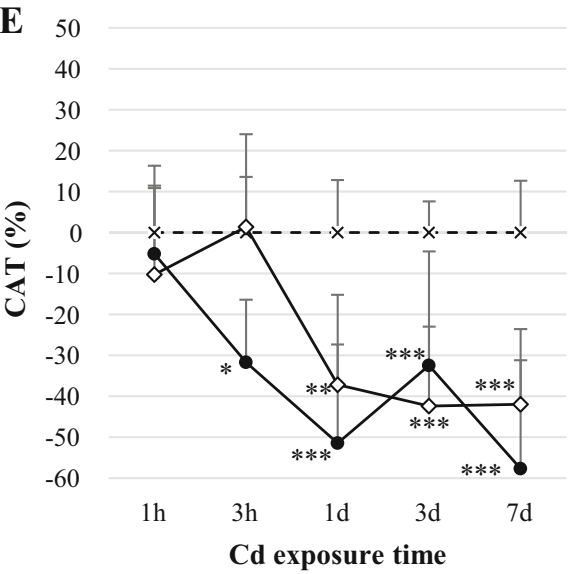

B

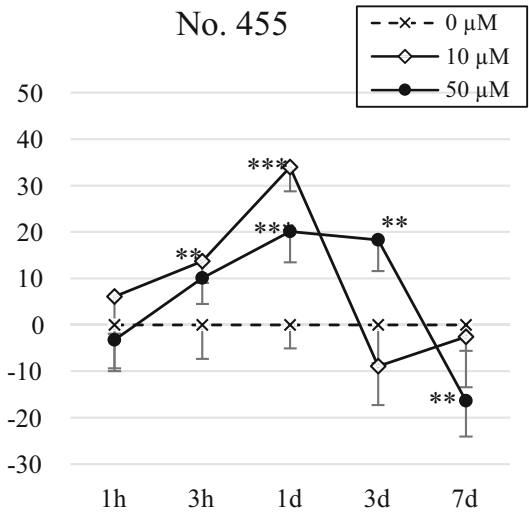

D

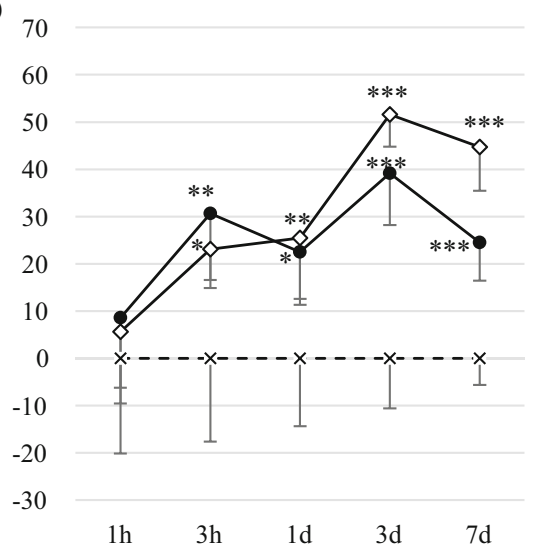

F 50

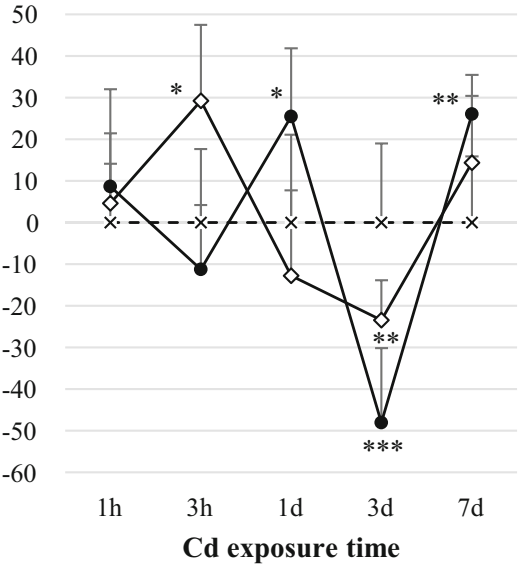

molecule and regulates peroxidases expression (Schützendübel et al. 2001). The expression analyses of APX showed fluctuation in transcript levels (Fig. 1a, b). Induction of APX transcription in early hours of stress corresponded with increase in APX activity. It is noteworthy that APX was the only antioxidative enzyme gene induced shortly after $\mathrm{Cd}$ exposure in $Q$. robur plants from both regions of origin. Thus, we presume that APX, along with SOD, constitutes first barrier to oxidative stress caused by $\mathrm{Cd}$ in pedunculate oak leaves.
Heavy metal tolerance in plants requires fast activation of appropriate protective mechanisms, therefore regulation of antioxidative enzymes gene expression is of special interest, as it may strongly affect plant stress response (DalCorso et al. 2008). Our study revealed that Cd induced stress caused significant changes in transcription of selected genes encoding antioxidative enzymes. For instance, CAT expression was significantly decreased at transcriptional level in plants from both regions of origin (Fig. 3e, f). In accordance to this, No. 659 seedlings showed 
decreased CAT activity (Fig. 3e). Similar reaction of CAT activity to Cd stress was reported by Mishra et al. (2006), Shi et al. (2010) and Mohapatra and Dey (2012). The decline of CAT activity in response to Cd stress might be not only due to decrease in its transcription, but it may also be the result of CAT inhibition by $\mathrm{O}_{2}^{--}$and HO (Skórzyńska-Polit et al. 2003). Contrary to No. 659 seedlings, No. 455 seedlings exhibited different trend of response (Fig. 3f), showing CAT stimulation in early hours of stress, then the decline in its activity followed by final increase. The induction in CAT activity in response to Cd stress was previously reported by Dinakar et al. (2009), Hsu and Kao (2004) and Nikolić et al. (2008).

Of particular note is the profile of antioxidative enzyme activities obtained in 7th day of stress in plants subjected to higher Cd dose (Fig. 3a-f). In No. 455 seedlings, SOD activity was declined, APX remained elevated whereas CAT activity was increased. In No. 659 seedlings under the same conditions, both SOD and APX activity remained elevated while CAT activity was declined. Plants from both regions of origin experienced oxidative stress in this time point as was indicated by LPO level, however, the oxidative damage observed in No. 659 plants was higher (data not shown; $p \leq 0.001$ ) than that observed in No. 455 plants. As SOD catalyzes the dismutation of $\mathrm{O}_{2}^{--}$to $\mathrm{H}_{2} \mathrm{O}_{2}$, and both CAT and APX participate in $\mathrm{H}_{2} \mathrm{O}_{2}$ detoxification, the balance between the activity of SOD and $\mathrm{H}_{2} \mathrm{O}_{2}$-scavenging enzymes is crucial during oxidative stress (Apel and Hirt 2004; Mittler 2002). According to Mittler (2002), APX might participate in the removal of fine amounts of $\mathrm{H}_{2} \mathrm{O}_{2}$ whereas CAT is involved in detoxification of high levels of $\mathrm{H}_{2} \mathrm{O}_{2}$ produced during stress. The obtained results might be explained by possible accumulation of $\mathrm{H}_{2} \mathrm{O}_{2}$ in No. 659 plants caused by increased SOD activity combined with decreased CAT activity. Although the No. 659 plants sustained elevated APX activity throughout the experiment, the lack of CAT activation might have been a reason for insufficient $\mathrm{H}_{2} \mathrm{O}_{2}$ removal and subsequent oxidative damage. This would imply that CAT is the key enzyme participating in long-term response to oxidative stress caused by $\mathrm{Cd}$ in $Q$. robur leaves. The results are in line with the study performed by Wen et al. (2012) which revealed that $\mathrm{Cd}$ exposure induced two waves of $\mathrm{H}_{2} \mathrm{O}_{2}$ accumulation in tobacco cells. In early phase of $\mathrm{Cd}$ stress, low concentration of $\mathrm{H}_{2} \mathrm{O}_{2}$ trigged adaptive responses, while prolonged $\mathrm{Cd}$ stress caused high accumulation of $\mathrm{H}_{2} \mathrm{O}_{2}$ that induced severe oxidative damage leading to cell death.

Heavy metal tolerance is often linked to high constitutive level of antioxidative enzymes (Landberg and Greger 2002; Sharma and Dietz 2009). In our study No. 455 plants, which exhibited significantly higher SOD and APX activities in control conditions, experienced lower oxidative damage by Cd exposure than No. 659 plants. We suppose that due to high constitutive level of antioxidative enzyme activities, No. 455 seedlings may have ability to react faster to potential oxidative stress than seedlings from the other region of origin.

In conclusion, obtained results indicate that APX and SOD play a first barrier role in oak seedlings response to the oxidative stress caused by $\mathrm{Cd}$ treatment. CAT is involved in reducing the negative effects of prolonged exposure of oak seedlings to $\mathrm{Cd}$. To our best knowledge, this is the first report on $Q$. robur antioxidative system response to $\mathrm{Cd}$ treatment, including both transcript and enzyme activity analyses. It provides better insight into the basics of pedunculate oak's tolerance to $\mathrm{Cd}$ exposure, which is of great significance in the view of possible use of this tree species for afforestation of heavy metal contaminated sites.

Open Access This article is distributed under the terms of the Creative Commons Attribution 4.0 International License (http://crea tivecommons.org/licenses/by/4.0/), which permits unrestricted use, distribution, and reproduction in any medium, provided you give appropriate credit to the original author(s) and the source, provide a link to the Creative Commons license, and indicate if changes were made.

\section{References}

Aebi H (1984) Catalase in vitro. Methods Enzymol 105:121-126

Anjum NA, Umar S, Ahmad A, Iqbal M (2008) Responses of components of antioxidant system in moongbean genotypes to cadmium stress. Commun Soil Sci Plant Anal 39:2469-2483

Apel K, Hirt H (2004) Reactive oxygen species: metabolism, oxidative stress, and signal transduction. Annu Rev Plant Biol 55:373-399

Arena C, Santorufo L, Cataletto PR, Memoli V, Scudiero R, Maisto G (2017) Eco-physiological and antioxidant responses of holm oak (Quercus ilex L.) leaves to $\mathrm{Cd}$ and $\mathrm{Pb}$. Water, Air, Soil, Pollut 228:459

Balakhnina TI, Bulak P, Matichenkov VV, Kosobryukhov AA, Włodarczyk TM (2015) The influence of Si-rich mineral zeolite on the growth processes and adaptive potential of barley plants under cadmium stress. Plant Growth Regul 75:557-565

Benavides MP, Gallego SM, Tomaro ML (2005) Cadmium toxicity in plants. Braz J Plant Physiol 17:21-34

Bradford MM (1976) A rapid and sensitive method for the quantitation of microgram quantities of protein utilizing the principle of protein dye binding. Anal Biochem 72:248-254

DalCorso G, Farinati S, Maistri S, Furini A (2008) How plants cope with cadmium: staking all on metabolism and gene expression. J Integr Plant Biol 50:1268-1280

Dinakar N, Nagajyothi PC, Suresh S, Damodharam T, Suresh C (2009) Cadmium induced changes on proline, antioxidant enzymes, nitrate and nitrite reductases in Arachis hypogaea L. J Environ Biol 30:289-294

Ekmekçi Y, Tanyolac D, Ayhan B (2008) Effects of cadmium on antioxidant enzyme and photosynthetic activities in leaves of two maize cultivars. J Plant Physiol 165:600-611

El-Beltagi HS, Mohamed AA, Rashed MM (2010) Response of antioxidative enzymes to cadmium stress in leaves and roots of 
radish (Raphanus sativus L.). Notulae Scientia Biologicae 2:76-82

Figlioli F, Sorrentino MC, Memoli V, Arena C, Maisto G, Giordano S, Capozzi F, Spagnuolo V (2019) Overall plant responses to Cd and $\mathrm{Pb}$ metal stress in maize: growth pattern, ultrastructure, and photosynthetic activity. Environ Sci Pollut Res 26:1781-1790

Gaudet M, Pietrini F, Beritognolo I, Iori V, Zacchini M, Massacci A, Mugnozza GS, Sabatti M (2011) Intraspecific variation of physiological and molecular response to cadmium stress in Populus nigra L. Tree Physiol 31:1309-1318

Ge W, Jiao YQ, Sun BL, Qin R, Jiang WS, Liu DH (2012) Cadmiummediated oxidative stress and ultrastructural changes in root cells of poplar cultivars. S Afr J Bot 83:98-108

Giannopolitis CN, Ries SK (1977) Superoxide dismutases. I. Occurrence in higher plants. Plant Physiol 59:309-314

Gogorcena Y, Larbi A, Andaluz S, Carpena RO, Abadía A, Abadía J (2011) Effects of cadmium on cork oak (Quercus suber L.) plants grown in hydroponics. Tree Physiol 31:1401-1412

Gonnelli C, Galardi F, Gabbrielli R (2001) Nickel and copper tolerance and toxicity in three Tuscan populations of Silene paradoxa. Physiol Plant 113:507-514

He J, Ma C, Ma Y, Li H, Kang J, Liu T, Polle A, Peng C, Luo ZB (2013) Cadmium tolerance in six poplar species. Environ Sci Pollut Res 20:163-174

Hsu YT, Kao CH (2004) Cadmium toxicity is reduced by nitric oxide in rice leaves. Plant Growth Regul 42:227-238

Khan NA, Singh S, Nazar R (2007) Activities of antioxidative enzymes, sulphur assimilation, photosynthetic activity and growth of wheat (Triticum aestivum) cultivars differing in yield potential under cadmium stress. J Agron Crop Sci 193:435-444

Landberg T, Greger M (2002) Differences in oxidative stress in heavy metal resistant and sensitive clones of Salix viminalis. J Plant Physiol 159:69-75

Le Provost G, Herrera R, Ap Paiva J, Chaumeil P, Salin F, Plomion C (2007) A micromethod for high throughput RNA extraction in forest trees. Biol Res 40:291-297

Livak KJ, Schmittgen TD (2001) Analysis of relative gene expression data using real-time quantitative PCR and the $2^{-\Delta \Delta C T}$ method. Methods 25:402-408

Malecka A, Piechalak A, Zielińska B, Kutrowska A, Tomaszewska B (2014) Response of the pea roots defense systems to the twoelement combinations of metals $(\mathrm{Cu}, \mathrm{Zn}, \mathrm{Cd}, \mathrm{Pb})$. Acta Biochim Pol 61:23-28

Martínez Domínguez D, Córdoba Garcí F, Canalejo Ray A, Torronteras Santiago R (2010) Cadmium-induced oxidative stress and the response of the antioxidative defense system in Spartina densiflora. Physiol Plant 139:289-302

Marum L, Miguel A, Ricardo CP, Miguel C (2012) Reference gene selection for quantitative real-time PCR normalization in Quercus suber. PLoS One 7:e35113. https://doi.org/10.1371/journal. pone.0035113

Mihucz VG, Csog A, Fodor F, Tatár E, Szoboszlai N, SilaghiDumitrescu L, Záray G (2012) Impact of two iron (III) chelators on the iron, cadmium, lead and nickel accumulation in poplar grown under heavy metal stress in hydroponics. J Plant Physiol 169:561-566

Mishra S, Srivastava S, Tripathi RD, Govindarajan R, Kuriakose SV, Prasad MNV (2006) Phytochelatin synthesis and response of antioxidants during cadmium stress in Bacopa monnieri L. Plant Physiol Biochem 44:25-37

Mittler R (2002) Oxidative stress, antioxidants and stress tolerance. Trends Plant Sci 7:405-410

Mohapatra S, Dey SK (2012) Physiological response of Hydrilla verticillata (l.f.) Royle exposed to cadmium stress. J Life Sci 6:55-60
Nakano Y, Asada K (1981) Hydrogen peroxide is scavenged by ascorbate-specific peroxidase in spinach chloroplasts. Plant Cell Physiol 22:867-880

Nikolić N, Kojić D, Pilipović A, Pajević S, Krstić B, Borišev M, Orlović S (2008) Responses of hybrid poplar to cadmium stress: photosynthetic characteristics, cadmium and proline accumulation, and antioxidant enzyme activity. Acta Biologica Cracoviensia Series Botanica 50:95-103

Paoletti E, Günthardt-Goerg MS (2006) Growth responses and element content of Quercus pubescens seedlings under acidic and heavy metal contamination. For Snow Landsc Res 80:323-337

Rodríguez-Serrano M, Romero-Puertas MC, Pazmiño DM, Testillano PS, Risueño MC, Luis A, Sandalio LM (2009) Cellular response of pea plants to cadmium toxicity: cross talk between reactive oxygen species, nitric oxide, and calcium. Plant Physiol 150:229-243

Rubio MC, James EK, Clemente MR, Bucciarelli B, Fedorova M, Vance CP, Becana M (2004) Localization of superoxide dismutases and hydrogen peroxide in legume root nodules. Mol Plant Microbe Interact 17:1294-1305

Schützendübel A, Schwanz P, Teichmann T, Gross K, LangenfeldHeyser R, Godbold DL, Polle A (2001) Cadmium-induced changes in antioxidative systems, hydrogen peroxide content, and differentiation in Scots pine roots. Plant Physiol 127:887-898

Sharma SS, Dietz KJ (2009) The relationship between metal toxicity and cellular redox imbalance. Trends Plant Sci 14:43-50

Shi GR, Liu CF, Cai QS, Liu QQ, Hou CP (2010) Cadmium accumulation and tolerance of two safflower cultivars in relation to photosynthesis and antioxidantive enzymes. Bull Environ Contam Toxicol 85:256-263

Skórzyńska-Polit E, Drążkiewicz M, Krupa Z (2003) The activity of the antioxidative system in cadmium-treated Arabidopsis thaliana. Biol Plant 47:71-78

Sorrentino MC, Capozzi F, Amitrano C, Giordano S, Arena C, Spagnuolo V (2018) Performance of three cardoon cultivars in an industrial heavy metal-contaminated soil: effects on morphology, cytology and photosynthesis. J Hazard Mater 351:131-137

Spieß N, Oufir M, Matušíková I, Stierschneider M, Kopecky D, Homolka A, Burg K, Fluch S, Hausman JF, Wilhelm E (2012) Ecophysiological and transcriptomic responses of oak (Quercus robur) to long-term drought exposure and rewatering. Environ Exp Bot 77:117-126

Uchiyama M, Mihara M (1978) Determination of malonaldehyde precursor in tissues by thiobarbituric acid test. Anal Biochem 86:287-297

Wen JF, Deng MH, Gong M (2012) $\mathrm{Cd}^{2+}$ stress induces two waves of $\mathrm{H}_{2} \mathrm{O}_{2}$ accumulation associated with ROS-generating system and ROS-scavenging system in cultured tobacco cells. Aust J Crop Sci 6:846-853

Wójcik M, Skórzyńska-Polit E, Tukiendorf A (2006) Organic acids accumulation and antioxidant enzyme activities in Thlaspi caerulescens under $\mathrm{Zn}$ and $\mathrm{Cd}$ stress. Plant Growth Regul 48:145-155

Wu F, Zhang G, Dominy P (2003) Four barley genotypes respond differently to cadmium: lipid peroxidation and activities of antioxidant capacity. Environ Exp Bot 50:67-78

Wu Z, Zhao X, Sun X, Tan Q, Tang Y, Nie Z, Qu C, Chen Z, Hu C (2015) Antioxidant enzyme systems and the ascorbate-glutathione cycle as contributing factors to cadmium accumulation and tolerance in two oilseed rape cultivars (Brassica napus L.) under moderate cadmium stress. Chemosphere 138:526-536

Publisher's Note Springer Nature remains neutral with regard to jurisdictional claims in published maps and institutional affiliations. 